\title{
KPO's: India's Ascension to the Top of the World
}

\author{
Shishira Srinivasa, L.Vijayashree
}

\begin{abstract}
In the global scenario, technological advances and the growth of the information industry provided new market opportunities. Since business processing at low levels, multinational companies have begun outsourcing value-added ways of outsourcing of business processes. This has created a new outsourcing pattern, Knowledge Process Outsourcing, KPO. This covers intellectual property, equity and finance research and research, analysis, business research and data processing etc. After performance in BPOs, India is now focusing on KPOs. It is estimated that this business would hire 250,000 people by 2010. This paper addresses questions concerning the outsourcing of knowledge processes in terms of the Hecksher Ohlin model. It examines new developments in India's KPO market. It provides an outlook on the benefits of India in KPO and its evolving economic prospects. It also underlines the problems facing the next KPO market. Implementation of policies on challenges is often debated.

Keywords: KPOs, India and KPOs, Challenges faced, Trends in KPOs
\end{abstract}

\section{INTRODUCTION}

The planet today is seeing a dramatic shift from an industry to an economy dependent on intelligence. In the knowledge economy, knowledge density depends on information and know-how in productive processing. Highly qualified workers in the information and knowledge industries are the secret to growth (Skyrme 1997, Stiglitz 1999). Wissen jobs are referred to as the information experts employed in the knowledge economy. Wisdom employees are the workers of higher education standards and the output of their skills (Taylor 1998). Also in an information economy, a nation has a competitive strategic advantage over its human capital or inexpensive labour (World Development Report). KPO, or Knowledge Process Outsourcing, has arisen from the evolution and sophistication of the Indian $\mathrm{BPO}$ industry. BPO is distinguished in strata depending on the degree of experience and skills needed for the work. The period needed to introduce goods and services has fallen as the global market is getting more dynamic. Customers need good service efficiency. Businesses have embraced organisational efficiency structures and business models.

Manuscript received on May 26, 2021.

Revised Manuscript received on June 03, 2021.

Manuscript published on June 30, 2021.

* Correspondence Author

Ms Shishira Srinivasa*, Management, BNM Institute of Technology, Bangalore (Karnataka), India. Email: shishibenbarnes@gmail.com

Dr L.Vijayashree, Professor, MBA Dept., Head-Entrepreneurship Development Cell- BNMIT, Chief- Coordinator- New Gen IEDC, DST, GoI, BNMIT, Bangalore (Karnataka), India. E-mail: Professor.bnmit@gmail.com

(C) The Authors. Published by Blue Eyes Intelligence Engineering and Sciences Publication (BEIESP). This is an open access article under the CC BY-NC-ND license (http://creativecommons.org/licenses/by-nc-nd/4.0/)
These market models often bring to their goods and services a competitive benefit. Many companies have also been exporting their advanced expertise to low-wage areas.

This phenomenon is referred to as outsourcing of the information process or KPO. Outsourcing of information requires the creation of market processes intensively knowledgeable that need advanced field experience (Evalueserve 2005, Sengupta 2005, Sen and Sheil 2006 ).

KPOs/BPOs: Market marketing, venture analysis, patent registration, regulatory, and procurement are all examples of high-end specialised activities and procedures that can be outsourced. as well as facts, to name a few. Which entails the outsourcing of judicial procedures. All of these types of business process outsourcing have a high level of added benefit (BPO). Rather than just method experience, KPO companies provide domain-based systems and industry expertise. Companies increasingly progress from low-cost to high-cost outsourcing. Programming and maintenance were the first steps in the IT sector. It has increasingly developed into a corporate model that is based on information technology. From contact centres and client service, the insurance sector has progressed to Underwriting and Asset Management. Data Search and Integration \& Management are projected to expand at the fastest rate among the fast-moving verticals within the KPO domain, with a CAGR of nearly 50\% and a market size of USD 5 billion by 2020 . The market research and business intelligence industries are expected to expand at a CAGR of nearly 54 percent. Engineering and design, animation and simulation services, paralegal content and services, e-learning, and paralegal content and services are a few sectors that are still developing but have a lot of promise.

Financial Services and Insurance Research, Biotech and Pharmaceuticals, Research and Development, and Equity The core philosophy of a KPO is to have domain knowledge rather than mechanism to generate value for the consumer.

New market opportunities have emerged as a result of technological advancements and the growth of information industries across the world. Outsourcing is one of the most profitable industry ventures. Global companies have been outsourcing high-value-added ways of business process outsourcing after outsourcing low-end business processing. Knowledge Process Outsourcing, or KPO, has emerged as a recent development in outsourcing, encompassing analysis and work on intellectual property, equity and finance, analytics, business research, and business processing, among other things. India is focusing on KPOs now that it has achieved performance in BPOs. By 2010, this industry is estimated to recruit 250,000 people (Evalueserve 2005). As a result, the growing KPO industry has significant consequences for the Indian economy.

Blue Eyes Intelligence Engineering \& Sciences Publication (BEIESP)

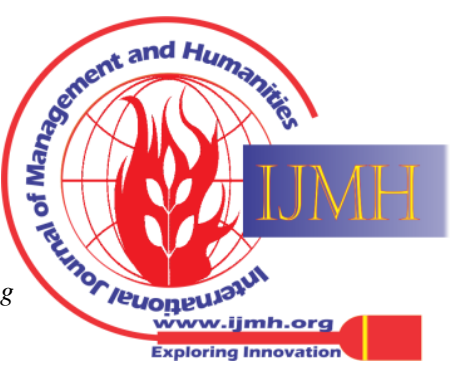




\section{KPO's: India's Ascension to the Top of the World}

The Indian economy is affected significantly by outsourcing. Despite its importance, there is a scarcity of appropriate research literature in this region. Sargeant (2006) reviewed the current outsourcing partnership literature and identified areas of interest for more research, such as the customer-vendor relationship. The value of the consumer provider was established in the research.

As a predictor of outsourcing performance, consider your partnership. Jiang and Quereshi (2006) surveyed the literature on outsourcing and provided a guide for future research using data from 1990 to 2003 to provide a roadmap for future research on outsourcing performance. They identified three significant holes in outsourcing analysis, as well as potential research prospects. The theoretical dimensions of outsourcing were examined in these articles.

Bhattacharya (2005) looked at the problems that Indian businesses face when it comes to KPO services in the financial services industry. This was a sector-specific study outsourcing (BPO) companies in India face management problems and prospects, according to Mehta et al. (2006). They spoke with executives from 15 BPO companies. Human capital and organisational problems became critical concerns. Knowledge Process Outsourcing has been described as a potential future revenue stream. information process outsourcing from both the customer and vendor viewpoints. The concerns are based on five events that the authors investigated in India and Ireland.

Outsourcing challenges have been illustrated in the literature, according to the study. However, it seems that little study has been conducted on the importance of KPOs to the Indian economy and the problems they face. These problems are investigated in this article. The below are the major topics that the paper would address:

1. The Heckser Ohlin model explains the growing global developments in KPO.

2. Emerging KPO patterns in India, as well as areas of specialisation

3.India's competitive advantages in KPO and the economy's emerging potential face

4. The challenges that the forthcoming KPO section will

5. Implementation of policies in the KPO market

\section{Trends in KPOs:}

One of the biggest business trends in the 1990s was outsourcing. Contracting with a seller, which might or may not have any degree of offshoring, is what outsourcing entails (wikipedia). Outsourcing business operations resulted in cost savings of 80-90 percent, increased access to emerging technologies, and enabled a company to concentrate on its core competencies. (EIU 1995, Petrie 2000).

Offshoring high-end operations to low-wage destinations is expected to result in cost reductions, operating efficiencies, access to a highly skilled workforce, and increased productivity. The outsourcing agency concentrates on wider industry concerns or has a finer competitive orientation, whilst an independent consultant handles operating information (Petrie 2000; EIU/AA, 1995).

In a business sense, "outsourcing" refers to the process of transferring an operational role to a third party. It's possible that the third party is based in a different region (wikipedia). Outsourcing is described as "an agreement under which one report that focused solely on the problems. Business process

Sen and Falguni (2006) looked at problems around

business offers resources to another company that would otherwise have been applied in-house," according to other definitions. Skyes (Skyes, 2004).

The transition of administration and/or day-to-day execution of an entire company function to an external service ccontractor is known as outsourcing (Overby 2007). Outsourcing is described as "the transition to third parties of the execution of functions that were previously performed in-house." There are two categories of services that are offered through outsourcing: ITO (Information Technology Outsourcing) entails contracting a third party to handle a specific programme, with its associated computers, networks, and technological updates. BPO (Business Process Outsourcing) is described as "the management of an entire business process, such as accounting, acquisition, or human resources, by a third party." Skyes (Skyes, 2004). Market analysis, investment research, patent registration, regulatory, and procurement and records, among other high-end complex activities and processes, are all examples of knowledge process outsourcing.

Initially, multinational corporations outsourced lower-qualified industry operations to countries with a strong skilled labour pool. BPO, or Business Process Outsourcing, was the name given to this phenomenon (BPO). This is a market model in which a corporation contracts out such functions to a service provider, and then returns the role to the company. Customer care, tax, accounting, mortgage, and wealth management are only a few of the services provided by BPOs.

In 2008, the largest 100 outsourcing companies had a total revenue of about 1.7 billion dollars and hired about 27,000 people (WNS 2008). The slowing of the US economy as a result of the recession can hasten the phase of cost cutting, resulting in a rise in outsourcing to low-cost countries.

In the field of business process outsourcing, or BPO, India has established itself as a global leader. BPO's contribution was 2.78 billion dollars in 2003, and it is projected to rise at a pace of 26\% per year until 2010. (Evalueserve 2005). On the list of outsourcing companies, Indian companies are at the top. In 2008, 20 Indian companies were ranked among the top 100 outsourcing companies in the world (WNS 2008).

Firms like Tech Mahindra and HCL Technologies are credited for having extensive outsourcing expertise.

\section{Analysis of Heckscher Ohlin theory as a basis of Comparative Advantage in KPO Industries:}

The fundamental premise of Hecksher Ohlin's model is that a nation sells products that make extensive use of its comparatively abundant natural resources.

A plentiful manufacturing element That is, countries export the products for which they are ideally adapted, based on their resources endowment of the factor. In the KPO industry, the Heckscher Ohlin model is used to determine competitive advantage.

Differences in comparative benefit, according to Heckscher-Ohlin, are caused by differences in factor abundance and in factor distribution.

Published By:

Blue Eyes Intelligence Engineering

\& Sciences Publication (BEIESP)

DOI:10.35940/ijmh.J1326.0651021

Journal Website: www.ijmh.org

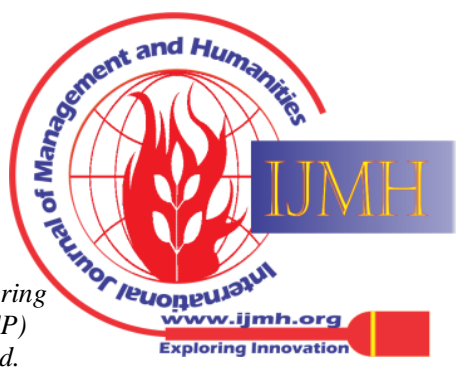


The degree to which products have a factor strength The Heckscher-Ohlin model does not take into account variations in Total Factor Productivity across industries.

In a particular sector, it is assumed that all countries have the same output function. There may be specialisation in the manufacture of products in a single industry because of their competitive advantage in production and trading.

Though specialisation does not have to be full, it is recommended. There are a number of economic models that can be used to examine the situation.

Patterns of specialisation and competitive benefit A competitive advantage in development is explained by Hechscher-Ohlin, by contrasting a country's relative endowment of economic development factors inside and through countries.

The nation would manufacture products with the most intense use of the abundant element, potentially leading to specialisation, a particular industry (Alexander Kindleberger) Different nation have different factor endowments as a result of their geographical, historical, and cultural characteristics, historical significance. Qualified labour and trained manpower are usually in short supply in knowledge sectors.

- India is a nation with a high labor-intensive economy. India has the biggest pool of workforce capable of providing effective service.

- The world's second-largest pool of scientists, operators, and engineers. Thousands of people have died in India as a result of the floods.

- They have access to high-quality schooling, but their salaries are poor as opposed to their peers in other countries.

- Countries that have been formed Professionals were forced to relocate to other developing countries as a result of this. Human capital with a strong foundation

- The future of information process outsourcing would undoubtedly be determined by low employment, in addition to low wages.

\section{Value proposition for KPO Outsourcing}

Both the consumer and the vendor profits from outsourcing. Prior to globalisation, the revenue distribution of a conventional management-consulting company in the United States was $20 \%$ fixed costs, $60 \%$ operating costs, and $20 \%$ profit margins.

Following outsourcing, rates are $18 \%$ fixed, $30 \%$ adjustable, and $20 \%$ gross margins. This results in investment, which generates a benefit of 32\% for KPO firms' "clients." As a consequence, firms' efficiency increases.

The revenues of the KPO vendors are obtained from the client's variable cost. Overhead expenses for KPO sellers, such as telecom, logistics, catering, and infrastructure costs, account for $30 \%$ of typical KPO revenue. In terms of profit and work growth, this has a multiplier effect (Evalueserve 2005).

Because of a scarcity of highly skilled labour, developed countries are increasingly turning to outsourcing. Offshoring is becoming more common in India. To fix a labour shortage, outsourcing can be included. Figure 1 depicts the need for and supply of labour in the United States in 2010. There would be a 5.6 million labour supply deficit in 2010. The offshoring of 1.3 million jobs will contribute to the filling of the hole (Evalueserve 2005).

Companies are offshoring their services to take advantage of minimum wage structures in many countries, as well as cost reductions. As a consequence, they will save money. Outsourcing often enables companies to take advantage of time zone shifts in order to maximise flexibility (such as adding another shift of work). As a result, products and services will hit consumers more easily. It is possible to gain entry to a vast and improved talent stream. Offshoring is often the manifestation of a need to localise a product or service (Pandey et al 2004).

The Indian KPO industry has tremendous opportunities for SMEs. SME rates can be tailored to meet short-term demands, allowing for the growth of new business models. When it comes to outsourcing, small and medium-sized companies have an edge. Small companies will easily outsource their operations. Many additional services are already outsourced, assisting in the achievement of scale economies.

\section{Skills required in Knowledge Process Outsourcing:}

Since the work necessitates specialised knowledge, the need for manpower in KPO is very specific, with a heavy focus on educational qualifications. The job includes abstracting technological patents, deleting legacy technical information, cataloguing and indexing, taxonomy creation, and database building and updating.

Table 2 lists some of the most relevant KPOs as well as the skills that are accessible. Much of this requires a fundamental curiosity in and knowledge of specific domains, as well as the capacity to work with evidence and information. These procedures necessitate the use of knowledgeable personnel with advanced theoretical and specialised expertise. Table 4 depicts India's dominance in various KPO parts.

Companies provide a cut-off for marks based on the level of domain knowledge required for the project (grades). As a result, the study requires that individuals have the necessary aptitude and temperament for performing research. After being hired, candidates are trained in a number of techniques. Aside from that, the candidate must have outstanding organisational skills, programming aptitude, and the capacity to work in a team, under pressure, and on a range of shift schedules (Manu, 2005).

KPO may be a lucrative job path for budding intelligence experts. The KPO industry offers a friendly working atmosphere, global exposure, and the opportunity to broaden one's skill set in a specialised field. A two-year experience person can expect to earn between Rs 6 lakh (Rs 600,000) and Rs 8 lakh (Rs 800,000) per year, while an experienced specialist can expect to earn between Rs 15 lakh (Rs 1.5 million) and Rs 20 lakh (Rs 20 lakh) per year (Rs 2 million). According to reports, the average annual salary in the KPO sector in India is about $\$ 8000$, compared to $\$ 6000$ in the BPO sector (Manu 2005).Companies such as Evalueserve, GE Capital, and MarketRx have produced KPOs in India. Evalueserve has a presence in Gurgaon.

Published By:

Blue Eyes Intelligence Engineering \& Sciences Publication (BEIESP)

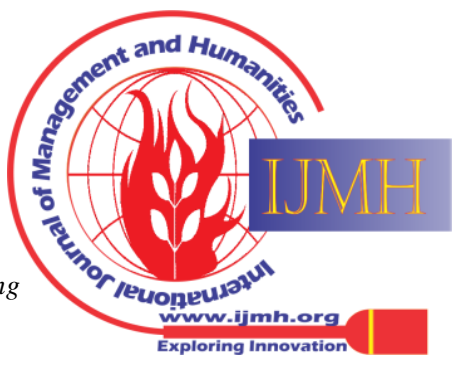




\section{KPO's: India's Ascension to the Top of the World}

Patent Metrix, Cantor-Colburn and Schwegman, Lundberg, and Woessner \& Kluth are among the law firms that have established offices in India. Two of the world's largest pharmaceutical firms, Astra Zeneca and GlaxoSmithKline, have developed drug discovery centres in low-cost locations to boost their research and development activities. Large telecom and IT firms look to India for R\&D in technology and chip design. Motorola, Intel, IBM, Cisco, Texas Instruments, Nokia, and Philips have formed offshore design centres in India. In Bangalore, Microsoft has founded a research and development centre. Some American law firms have developed captive centres in India. Others are collaborating with Indian firms to accomplish the same aim. GE hires 2,000 employees at its Bangalore research centre. More than $80 \%$ of Efunds' employees are located in India. Evalueserve employs 600 people in India, out of a total of 650 people worldwide.

\section{INDIA AND BPO/KPO}

When understanding this evolution, the strengths of India as a destination and driver of the KPO phenomenon must be understood. Analysts predict that a KPO assignment would result in a $50 \%$ cost benefit, which is one of the most powerful generators of KPO. Another significant aspect is the scarcity of skilled human capital in developed countries such as the United States and the United Kingdom. The United States is expected to see a 5.6 million skilled professional shortage by 2010, whilst the United Kingdom is expected to face a 700,000 skilled professional shortage. This, along with the cost advantage, has resulted in the KPO business enjoying high annualised development.

\section{Offshoring Competitiveness Index}

India is regarded as an ideal location for KPO. India secured the highest rating in the Position Attractiveness Index. According to a 2004 AT Kearney poll, India ranked first in the offshoring attractiveness index due to low costs, as well as people skills and availability.

In a cross-country analysis, Table 3 contrasts India to other offshoring destinations. India's other rivals include Russia, China, the Czech Republic, the Philippines, Ireland, and Israel. India has a large knowledge base as well as cheaper costs. India's English language education system has been the country's most valuable commodity. Furthermore, India has a favourable demographic profile, with the majority of the population under the age of 35. The Philippines, Ireland, and Israel have small talent pools, while China and Russia have significant non-English speaking populations.

Table 4 depicts some of the fields in which countries have developed expertise. Several countries are currently attempting to gain skills in specific KPO areas. Russia is being marketed as an attractive venue for KPOs in the healthcare and technology fields. The Philippines has established itself as a successful animation outsourcing destination.

\section{India's Educational System}

India's most valuable commodity in KPO is its educational infrastructure. Science was at the heart of the ancient Indian educational system. The British developed a strong English-language education system, which provided India with a comparative advantage.

There is a well-developed tertiary education system in India. There is a significant supply of highly skilled labour.
Indians have a natural talent for science and production. A major value is a low cost advantage owing to currency valuation. India and the United States are also democratic nations.

The proximity of the two countries is often advantageous.

Because of the huge talent pool, low prices, and strong research facilities, several multinational companies are building $R \& D$ centres in India. These research and development centres benefit both developing and developed countries. India has the largest number of scientific and technological practitioners in the world, second only to the United States. India has six times the number of university students as China.

People of diverse backgrounds apply to the manpower pool. Engineers, MBAs, financial analysts, and even journalists may apply for positions at KPO. People with science backgrounds have a better chance that such tasks include data analysis and programming. The rich educational experience of India creates a diverse pool of expertise workers in a broad range of fields, including pharmacy, medicine, law, biotechnology, education and training, engineering, analytics, architecture and animation, research and development, paralegal content, and even intelligence services.

India has an excellent school infrastructure. There were 886 colleges for higher education in 1990-91, which increased to 3201 in 2004-2005.

\section{The market share of BPO is declining.}

Rising labour costs also culminated in a drastic increase in prices in the BPO industry. Wages in the BPO industry in India have grown by an average of 14 percent a year (Evalueserve analysis). If current patterns continue, they will be paying 2.5 times as much as they are today (in constant dollars) by 2010, cutting the cost-arbitrage benefit from $40 \%$ to $25 \%$. The cost of life in India has increased to the extent that it is no longer possible to provide low-cost services at a fair price (Dash \& Agarwal2005). Low-cost destinations like Ukraine, Belarus, and Malaysia can see a change in low-cost services. The commoditization of BPO facilities will hasten the transition of existing low-end destinations to the higher end of the value chain. As a consequence, in order to progress along the supply chain, companies must move from bpo to kpo. Companies would like to migrate to KPO since the returns would be higher.

\section{CONCLUSION}

India has a bright future in the region of KPO. India has a strategic edge in the area of information practise. It is important that we should not risk our competitive edge. Other countries can try to develop their skills, thus reducing our competitive advantage. If the above problems are adequately addressed, India will surely retain its human capital leadership and emerge as a global leader in KPO.

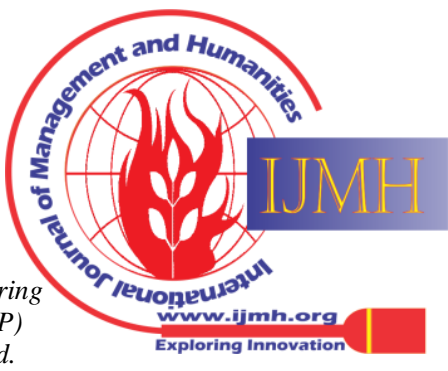




\section{REFERENCES}

1. A, T. Kearney. (2007). A T Kearney's 2004 Offshore Location Attractiveness Index, Making Offshore decisions, ATKearney.pdf, accessed last 1st aug, 2007.

2. Bhattacharya, S (2005). Challenges for Indian Companies in the Financial Services KPO Business, Crisil Young thought leader series 2005, Dissertation, Faculty of Management Studies, University of Delhi.

3. Dash, S. \& Agarwal, R. (2005). Determining India's Edge in IT Outsourcing:A Cross Country Analysis of Comparative Advantage in IT , in Upadhay V.ed. et.al (2005) Productivity and Quality Research, Tata Mcgraw Hill, New Delhi.

4. EIU/AA (1995). (The Economist Intelligence Unit, written in cooperation with Arthur Andersen). New Directions in Finance: Strategic Outsourcing, New York:EIU.

5. Evalueserve (2004). The next big business opportunity, Moving up the value chain- form BPO to KPO, Business Research, July 13, www.evalueserve.com.

6. Evalueserve (2005). Knowledge Process Outsourcing - A win win situation, Analytics - India Desk Research, Evalueserve, 3 May. www.evalueserve.com.

7. GOI (2007). Selected Educational Statistics 2004-05, Ministry of MHRD, Dept. of higher Education, Statistics division, New Delhi.

8. Jha, V.(2005). Business and Knowledge process outsourcing, United Nations Conference on Trade and Development,32nd World Marketing Congress on Marketing of Human Resource: Worldwide Institute of Marketing and Management, New Delhi, January 29-31.

9. Jiang and Quereshi (2006). Research on outsourcing results:current literature and future opportunities. Management Decision, Vol. 44 No. 1, 2006 , pp. 44-55, Emerald Group Publishing Limited.

\section{AUTHORS PROFILE}

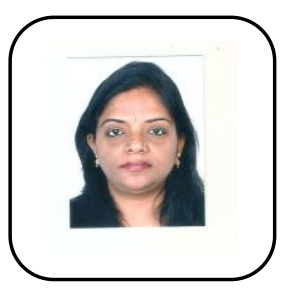

Dr. L. Vijayashree

Experience:

- Head-Entrepreneurship Development Cell- BNMIT and Chief- Coordinator- New Gen IEDC, DST, GoI, from 2017.

- Head and Professor of MBA - 3 Years, Academic experience in total -17 years, Industry experience - 4 years.

Journals \& book's Publication: 56 International Journal Paper and National Research papers (citation factor75). Also presented Research papers and won outstanding paper awards in International conferences held abroad and in India.

Published Books for undergraduate students in the areas of Business Environment, Organizational Behavior and Strategic Management.

Grants: Chief coordinator-Entrepreneurship Development Cell at BNMIT received many grants as Principal Investigator for the following Department of Science and Technology (DST) projects:

1. DST - NewGen IEDC (Innovation Entrepreneurship Development Cell) 2017- 2022

INR 2, 87, 50,000/- for students project prototype development.

2. DST - NIMAT(National Implementing and Monitoring Agency for Training) Project 2018 - 2019 -

INR. 2, 00, 000/- for 10 Entrepreneurship Awareness Camp.

3. DST - NIMAT(National Implementing and Monitoring Agency for Training) Project 2017 - 2018 -

INR. 1, 00, 000/- for 5 Entrepreneurship Awareness Camp.

4. DST - NIMAT(National Implementing and Monitoring Agency for Training) Project 2015 - 2016 -

IINR 40, 000/- for 2 Entrepreneurship Awareness Camp.

PhD Guidance: Three of the $\mathrm{PhD}$ research scholars are awarded Doctorate under VTU and two are in the verge of submitting their final thesis in the areas of Stress, E-Governance and change management, Leadership, Role Efficacy and Locus of control areas.

Journal Editorial Boards: AMC Indian Journal of Entrepreneurship, Member of scientific Technical committee and editorial Board on Arts Management and social sciences assisted by King Mongkut's University of Technology Thonburi, Thailand, Advisory editor of Mustang Journal of Law and Legal Studies, USA, Editorial Board Member for International Journal of Social Science Research, USA, Indian Journal of Entrepreneurship, Reviewers committee in International Journal of Human Resource management, FOREX -Technical Journal, CMS Journal of Management -India.

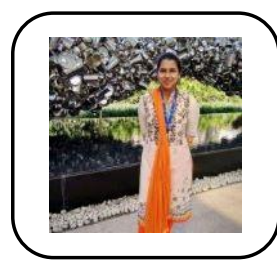

Ms. Shishira Srinivasa

1. Currently working as a Senior Tax Consultant at KPMG, Bangalore, and a Part time $\mathrm{PhD}$ Research Scholar at BNMIT, Bangalore.

2. Industry Experience: 5.5 years

3. Has authored a book on Stress management.

4. Journals and Publications: 11 National and International Journa publications and a chapter contribution in Perspectives of Business Management - Volume 1.

5. Presented papers at National conference and got them published in their Journals.

6. Is about to submit her thesis in less than 3 months' time in the area of stress management.

Table 2:

\begin{tabular}{|c|c|c|}
\hline Segments & Services & Skill sets required \\
\hline $\begin{array}{l}\text { Legal } \\
\text { services }\end{array}$ & $\begin{array}{l}\text { Reviewing } \\
\text { transactional \& } \\
\text { litigation documents; } \\
\text { drafting contracts; } \\
\text { research memoranda \& } \\
\text { due diligence reports; } \\
\text { prosecuting patents; } \\
\text { negotiations }\end{array}$ & $\begin{array}{l}\text { Knowledge in } \\
\text { US/UK laws; adept } \\
\text { in legal } \\
\text { application; ability } \\
\text { to reason \& } \\
\text { research }\end{array}$ \\
\hline $\begin{array}{l}\text { Engineering } \\
\text { R\&D }\end{array}$ & $\begin{array}{l}\text { 3D modeling; } \\
\text { conversion: 2D to 3D; } \\
\text { finite analysis; } \\
\text { computational fluid } \\
\text { dynamics analysis; } \\
\text { technical specifications } \\
\text { for tenders; value } \\
\text { engineering }\end{array}$ & $\begin{array}{l}\text { CAD/CAM; } \\
\text { drafting \& } \\
\text { modeling; product } \\
\text { design }\end{array}$ \\
\hline $\begin{array}{l}\text { Market } \\
\text { research \& } \\
\text { analytics }\end{array}$ & $\begin{array}{l}\text { Secondary \& primary } \\
\text { research; conversion of } \\
\text { findings to knowledge; } \\
\text { writing \& editing; } \\
\text { formatting } \\
\text { reports }\end{array}$ & $\begin{array}{l}\text { Statistical tools; } \\
\text { research } \\
\text { techniques; report } \\
\text { writing } \quad \text { \& } \\
\text { presentations; } \\
\text { database research }\end{array}$ \\
\hline
\end{tabular}

\begin{tabular}{|c|c|c|}
\hline $\begin{array}{l}\text { Writing } \\
\text { content } \\
\text { development } \\
\qquad \&\end{array}$ & $\begin{array}{lr}\text { Editorial; } & \text { content } \\
\text { delivery; digitization of } \\
\text { content; } \\
\text { enrichment data } \\
\text { warehousing; pre-press } \\
\text { work; proofreading; } \\
\text { template designing; } \\
\text { text composition } \\
\end{array}$ & $\begin{array}{l}\text { English } \\
\text { communication } \\
\text { skills; journalism; } \\
\text { experience in } \\
\text { writing }\end{array}$ \\
\hline $\begin{array}{l}\text { Pharma } \\
\text { R\&D }\end{array}$ & $\begin{array}{l}\text { Research \& } \\
\text { development; drug } \\
\text { discovery; clinical } \\
\text { research }\end{array}$ & $\begin{array}{l}\text { Doctors; master's } \\
\text { degree in science, } \\
\text { PhDs }\end{array}$ \\
\hline $\begin{array}{l}\text { Healthcare } \\
\text { services }\end{array}$ & $\begin{array}{l}\text { Diagnostic; genetic } \\
\text { profiling; oncology } \\
\text { tests; HIV \& allergy }\end{array}$ & $\begin{array}{l}\text { Medical } \\
\text { knowledge } \\
\text { degree; } \\
\text { specialized } \\
\text { subject } \\
\end{array}$ \\
\hline $\begin{array}{l}\text { Education } \\
\text { training } \\
\qquad \&\end{array}$ & $\begin{array}{l}\text { K-12; private tutors; } \\
\text { curriculum design; } \\
\text { pedagogy; content } \\
\text { development }\end{array}$ & $\begin{array}{l}\text { Teaching methods/ } \\
\text { techniques; cultural } \\
\text { sensitivity; online } \\
\text { teaching methods }\end{array}$ \\
\hline
\end{tabular}

Source: Source: Sathe \& Aradhana, Sourcingmag.com

Published By:

Blue Eyes Intelligence Engineering

\& Sciences Publication (BEIESP)

26 (C) Copyriaht: All riahts reserved.

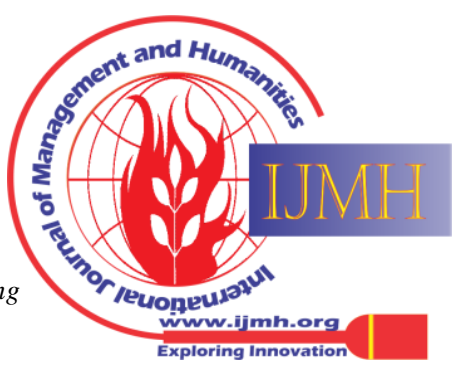


KPO's: India's Ascension to the Top of the World

Table 4. Countries capability in particular segment

\begin{tabular}{|c|c|}
\hline Segment & Country \\
\hline Animation & Philippines, India, China \\
\hline Content & India, Philippines \\
\hline Financial services & India, China \\
\hline Healthcare & Russia, India \\
\hline IT/R\&D & India, China, Russia \\
\hline Legal & New Zealand, India \\
\hline Pharma & India, Russia \\
\hline
\end{tabular}

Source: Sathe \& Aradhana, Sourcingmag.com

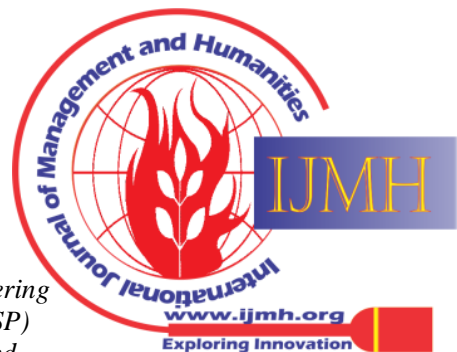

